\title{
AKTIVITAS ANTIOKSIDAN KULIT BUAH CEMPEDAK (Artocarpus integer (Thunb.) Merr.) ASAL KALIMANTAN SELATAN
}

\section{Antioxidant Activity Of Cempedak Fruit Skin (Artocarpus integer (Thunb.) Merr.) From South Kalimantan}

\section{Ali Rakhman Hakim "* \\ Rina Saputri'}

\section{Amanda Shelvia Savitri'}

\section{Anisa Ujuldah'}

Fitri Sadlia'

*IJurusan Farmasi Universitas Sari Mulia, Banjarmasin,

Kalimantan Selatan, Indonesia

*email:

alirakhmanhakim@unism.ac.id

Kata Kunci:
Antioksidan
Kulit buah cempedak
Artocarpus integer

Keywords:

Antioxidants

Cempedak fruit skin

Artocarpus integer

\begin{abstract}
Abstrak
Meningkatnya insiden penyakit yang berhubungan dengan stres oksidatif di antara populasi manusia telah mendorong peningkatan jumlah konsumsi antioksidan alami dalam makanan manusia. Tujuan dari penelitian ini adalah untuk mengetahui aktivitas antioksidan dari ekstrak kulit buah cempedak dengan pelarut etanol $50 \%$ dan etanol $70 \%$. Metode yang digunakan adalah pengujian aktivitas penghambatan radikal dengan metode DPPH (I,I - difenil - pikrilhidrazil) dan sebagai kontrol positif adalah vitamin C. Hasil dari skrining fitokimia diketahui mengandung fenolik, flavonoid, dan tanin. Hasil aktivitas antioksidan dari E50\% didapatkan nilai IC50 sebesar 650,07 ppm dan IC50 dari E70 sebesar 1219,69 ppm. Dari hasil tersebut dapat disimpulkan kulit buah cempedak tidak memiliki aktivitas antioksidan.
\end{abstract}

\begin{abstract}
The increasing incidence of diseases related to oxidative stress among the human population has led to an increase in the consumption of natural antioxidants in the human diet. The purpose of this study was to determine the antioxidant activity of cempedak fruit skin extract with $50 \%$ ethanol and $70 \%$ ethanol as solvents. The method used was testing of radical inhibitory activity with the DPPH method $(I, I$ - diphenyl - picrylhydrazil) and as a positive control was vitamin $C$. The results of phytochemical screening were known to contain phenolics, flavonoids, and tannins. The results of the antioxidant activity of E50\% obtained IC50 values of $650.07 \mathrm{ppm}$ and IC50 of E70 of $1219.69 \mathrm{ppm}$. From these results it can be concluded that the skin of the cempedak fruit does not have antioxidant activity.
\end{abstract}

\section{(c) (1) () (1)}

(C) year The Authors. Published by Institute for Research and Community Services Universitas Muhammadiyah Palangkaraya. This is Open Access article under the CC-BY-SA License (http://creativecommons.org/licenses/by-sa/4.0/). DOI: https://doi.org//0.33084/jsm.vxix.xxx.

\section{PENDAHULUAN}

Radikal bebas, atau reactive oxygen species (ROS), sering dihasilkan dalam tubuh manusia sebagai produk sampingan metabolisme, yang kemudian dinetralisir atau dikeluarkan dari tubuh oleh reaksi enzimatik endogen atau mikronutrien makanan. Namun, sistem pertahanan intrinsik seringkali tidak dapat melindungi biomolekul vital setelah aktivasi penginduksi stres oksidatif yang berlebihan. Meningkatnya insiden penyakit yang berhubungan dengan stres oksidatif di antara populasi manusia telah mendorong konsumsi peningkatan jumlah antioksidan alami dalam makanan manusia. Sejumlah penelitian juga telah menetapkan hubungan antara konsumsi makanan kaya antioksidan terhadap pencegahan penyakit manusia Jaradat \& Abualhasan, 2015).

Informasi yang ada menunjukkan bahwa peningkatan radikal bebas dan ROS dapat berkontribusi pada beberapa penyakit berat termasuk kanker, gangguan metabolisme, penyakit kardiovaskular dan penyakit Parkinson juga terkait dengan pembentukan ROS. Oleh karena itu, mempertahankan homeostasis ROS sangat penting untuk pertumbuhan dan kelangsungan hidup sel. Kerusakan yang disebabkan oleh pembentukan ROS dapat dicegah sampai tingkat tertentu dengan mekanisme pertahanan internal yang menggunakan enzim, seperti superoksida dismutase, katalase dan antioksidan. Namun, karena berbagai faktor lingkungan, seperti hormon lingkungan, alkohol, 
merokok, dan melemahnya mekanisme pertahanan, jumlah oksigen aktif dalam tubuh dapat meningkat pesat, dan mungkin tidak dapat melindungi diri dari kerusakan yang diakibatkannya (Chai et al., 2012; Kwon et al., 2020; Ndanusa et al., 2020).

Antioksidan adalah senyawa yang memiliki kemampuan untuk menetralisir atau mengurangi efek negatif radikal bebas, molekul yang memiliki elektron tidak berpasangan pada lingkaran luarnya. Dari berbagai hasil penelitian, antioksidan dilaporkan dapat memperlambat proses yang disebabkan oleh radikal bebas seperti adanya diet alami yang kaya akan fenolik dan flavonoid (Dewi et al., 2020).

Senyawa metabolit sekunder dari bagian tumbuhan dapat diambil dengan metode ekstraksi. Pemilihan pelarut untuk ekstraksi dapat mempengaruhi jumlah senyawa berkemampuan antioksidan. Umumnya pelarut yang digunakan adalah etanol. Pertimbangan penggunaan etanol adalah karena bersifat polar yang sesuai dengan sifat senyawa yang memiliki aktivitas antioksidan seperti flavonoid dan fenolik. Pertimbangan lain penggunaan etanol adalah efisien dan kurang toksik (Hakim \& Saputri, 2020).

Saat ini belum ditemukan hasil penelitian tentang aktivitas antioksidan dari kulit buah cempedak. Penelitian sebelumnya dari kulit buah cempedak adalah tentang pengujian toksisitas akut pada tikus putih galur wistar dan pengujian tentang kemampuan antimikroba pada Escherichia coli dan Staphylococcus aureus. Kulit buah cempedak diketahui mengandung saponin, tanin, flavonoid dan alkaloid (Hakim \& Saputri, 2018; Saputri et al., 2019). Tujuan untuk mengetahui aktivitas antioksidan dari kulit buah cempedak ini adalah untuk mencari alternatif baru dalam memenuhi kebutuhan akan senyawa antioksidan. Alternatif senyawa antioksidan baru yang didapatkan dapat meningkatkan manfaat dari kulit buah cempedak tersebut.

\section{METODOLOGI}

\section{Alat dan Bahan}

Alat yang digunakan pada penelitian ini adalah spektrofotometri UV-Vis, vortex mixer, refluks, dan perangkat maserasi.

Bahan yang digunakan pada penelitian ini adalah kulit buah cempedak, vitamin C (Merck), etanol (SmartLab), dan DPPH ( I, I - difenil - pikrilhidrazil) (Sigma).

\section{Metode Pelaksanaan}

Pembuatan ekstrak. Kulit buah cempedak diekstraksi menggunakan metode maserasi dan refluks. Masing-masing metode ekstraksi dilakukan menggunakan 2 jenis pelarut yaitu etanol $50 \%$ dan etanol 70\%. Kulit buah cempedak kering yang digunakan untuk masing-masing ekstraksi sebanyak 20 gram. Ekstraksi cara maserasi dilakukan selama 3 kali 24 jam, dengan setiap 24 jam pelarut diganti dengan yang baru. Filtrat hasil ekstraksi kemudian disaring dan diuapkan hingga didapatkan ekstrak kental. Hasil ekstraksi pelarut etanol 50\% diberi kode E50 dan hasil ekstraksi pelarut etanol 70\% diberi kode E70.

Skrining fitokimia. Senyawa kimia yang diidentifikasi adalah fenolik, flavonoid, dan tanin menggunakan prosedur yang telah teruji pada penelitian sebelumnya (Firdaus et al., 2021; Januarti et al., 2019; Wahyuni \& Hertiani, 2016).

\section{Penentuan aktivitas antioksidan dengan} metode DPPH. Pengujian aktivitas antioksidan metode DPPH (I,I - difenil - pikrilhidrazil) mengikuti metode Ndanusa et al, dengan sedikit perubahan. Larutan DPPH 0,I mM dibuat dari 9,858 mg DPPH dilarutkan dengan pelarut etanol $250 \mathrm{ml}$. Vitamin C digunakan sebagai kontrol positif. Vitamin C dan masing-masing ekstrak dibuat menjadi beberapa konsentrasi $(50,100,200$, dan 250) dengan satuan Ppm. Pengukuran aktivitas antioksidan melalui pembacaan absorbansi menggunakan spektrofotometri UV-Vis dengan panjang gelombang $515 \mathrm{~nm}$. Nilai antioksidan dinyatakan dengan IC50 $\mu g / m L(P p m)$ (Ndanusa et al., 2020).

\section{HASIL DAN PEMBAHASAN}




\section{Hasil}

Hasil dari skrining fitokimia ekstrak kulit buah cempedak (E50 dan E70) positif mengandung senyawa fenolik, flavonoid, dan tanin.

Tabel I. Hasil skrining fitokimia

\begin{tabular}{ccc}
\hline Senyawa & E50 & E70 \\
\hline Fenolik & + & + \\
Flavonoid & + & + \\
Tanin & + & + \\
\hline
\end{tabular}

Hasil pengujian aktivitas antioksidan ekstrak kulit buah cempedak (E50 dan E70) dapat dilihat pada tabel 2.

Tabel 2. Hasil uji aktivitas antioksidan

\begin{tabular}{cccc}
\hline Sampel & $\begin{array}{c}\text { Konsentrasi } \\
(\mathbf{p p m})\end{array}$ & \% Inhibisi & $\begin{array}{c}\text { IC50 } \\
\text { (ppm) }\end{array}$ \\
\hline Vitamin C & 50 & 27,12 & 222,043 \\
& 100 & 29,24 & \\
& 200 & 42,37 & \\
E50 & 250 & 58,05 & \\
& 50 & 8,05 & 650,07 \\
& 100 & 12,71 & \\
& 200 & 14,83 & \\
E70 & 250 & 15,68 & 1219,69 \\
& 50 & 5,08 & \\
& 100 & 14,41 & \\
& 200 & 16,10 & \\
& 250 & 22,03 & \\
\hline
\end{tabular}

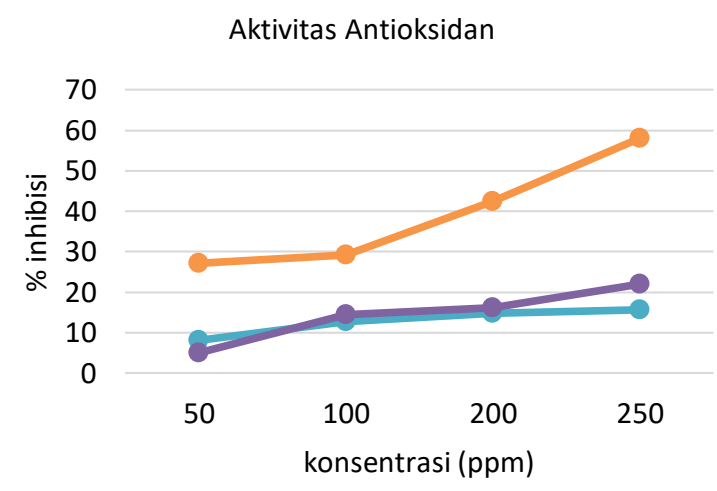

$\longrightarrow$ vitamin C $\longrightarrow$ E50 $\longrightarrow$ E70

Gambar I. Grafik aktivitas antioksidan

\section{Pembahasan}

Pada proses esktraksi, pemilihan metode ekstraksi dan pelarut yang digunakan sangat mempengaruhi hasil senyawa yang terekstraksi. Etanol adalah senyawa dengan rumus kimia $\mathrm{C} 2 \mathrm{H} 5 \mathrm{OH}$ yang memiliki gugus polar (hidroksil) yang lebih kuat daripada gugus karbon (nonpolar). Pemilihan pelarut etanol karena kemampuan mengekstrak senyawa polar seperti flavonoid, fenolik, dan tanin lebih banyak dibandingkan senyawa non polar (Saputri et al., 2019). Berdasarkan pengujian, ekstrak kulit buah cempedak E50 dan E70 positif mengandung senyawa fenolik, flavonoid, dan tanin.

Penelitian ini menguji aktivitas antioksidan dari ekstrak kental kulit buah cempedak E50 dan E70. Metode yang digunakan dalam uji aktivitas antioksidan adalah metode serapan radikal DPPH, pemilihan metode ini karena merupakan metode yang sederhana, mudah, dan menggunakan sampel yang sedikit. Pengujian proses penghambatan aktivitas radikal bebas dari DPPH (I,I - difenil - pikrilhidrazil) yang direndam dengan senyawa dari ekstrak yang diuji. Molekul DPPH merupakan molekul radikal bebas dengan adanya delokalisasi elektron di sekitar molekul. Adanya aktivitas antioksidan dari sampel pada perubahan warna larutan DPPH dalam metanol (Indarti et al., 2019). Besarnya aktivitas antioksidan ditentukan menggunakan nilai IC50, yaitu konsentrasi senyawa antioksidan yang dapat menghambat $50 \%$ radikal bebas. Mengacu kepada Jun et al, aktivitas antioksidan dikategorikan sebagai sangat kuat ketika IC50 <50 $\mu g / m L$, kuat jika nilai IC50 50-100 $\mu g / m L$, sedang jika nilai IC50 I0I-250 $\mu \mathrm{g} / \mathrm{mL}$, dan lemah jika nilai IC50 250-500 $\mu \mathrm{g} / \mathrm{mL}$, dan diklasifikasikan sebagai tidak aktif bila IC50 >500 $\mu \mathrm{g} / \mathrm{mL}$ (Jun et al., 2003).

Pada penelitian ini vitamin $C$ digunakan sebagai kontrol positif. Vitamin $\mathrm{C}$ telah diketahui sebagai senyawa antioksidan yang kuat. Berdasarkan hasil penelitian ekstrak kulit buah cempedak dengan E50 650,07 ppm dan E70 1219,69 Ppm masuk ke dalam kategori tidak aktif. Hal ini karena hasil IC50 kedua ekstrak berada dikelompok IC50 >500 $\mu \mathrm{g} / \mathrm{mL}$ (ppm) yang artinya tidak aktif sebagai senyawa antioksidan.

\section{KESIMPULAN}

Kulit buah cempedak yang diekstraksi dengan pelarut etanol 50\% dan pelarut etanol 70\% mengandung senyawa fenolik, flavonoid, dan tanin. Kulit buah cempedak tidak memiliki aktivitas antioksidan. 


\section{UCAPAN TERIMA KASIH}

Ucapan terima kasih diberikan kepada Mendikbudristek Republik Indonesia atas pendanaan yang diberikan serta Universitas Sari Mulia yang telah memfasilitasi pelaksanaan penelitian ini.

\section{REFERENSI}

I. Jaradat, N. A., \& Abualhasan, M. (20I5). Comparison in vitro of antioxidant activity between fifteen campanula species (bellflower) from Palestinian flora. Pharmacognosy Journal, 7(5), 276-279. https://doi.org//0.5530/pj.2015.5.4

2. Chai, T. T., Panirchellvum, E., Ong, H. C., \& Wong, F. C. (20/2). Phenolic contents and antioxidant properties of Stenochlaena palustris, an edible medicinal fern. Botanical Studies, 53(4), 439-446.

3. Kwon, H. Y., Choi, S. II, Park, H. I., Choi, S. H., Sim, W. S., Yeo, J. H., Cho, J. H., \& Lee, O. H. (2020). Comparative Analysis of the Nutritional Components and Antioxidant Activities of Different Brassica juncea Cultivars. Foods, 9(6), 413. https://doi.org//0.3390/foods 9060840

4. Ndanusa, A. H., Cicuzza, D., \& Siddique, M. M. (2020). Analysis of the phytochemical contents and anti-oxidative properties of Stenochlaena palustris. International Food Research Journal, 27(5), 798-804.

5. Dewi, D. Y. S., Ginting, C. N., Chiuman, L., Girsang, E., Handayani, R. A. S., \& Widowati, W. (2020). Potentials of rose (Rosa damascena) petals and receptacles extract as antioxidant and antihyaluronidase. Pharmaciana, 10(3), 343. https://doi.org/10.12928/pharmaciana.v10i3.16406

6. Hakim, A. R., \& Saputri, R. (2020). Narrative Review: Optimasi Etanol sebagai Pelarut Senyawa Flavonoid dan Fenolik. Jurnal Surya Medika, 6(I), I77-I80. https://doi.org/10.33084/jsm.v6il.164|

7. Hakim, A. R., \& Saputri, R. (2018). Analisis Toksisitas Akut Ekstrak Etanol Kulit Buah Cempedak pada Tikus Galur Wistar. Jurnal Pharmascience, 5(2), 173-184. https://doi.org/10.20527/jps.v5i2.5799
8. Saputri, R., Hakim, A. R., Syahrina, D., \& Lisyanti, F. (2019). Potensi Antimikroba Ekstrak Etanol Kulit Luar Buah Cempedak (Artocarpus integer (Thunb.) Merr.). Jurnal Surya Medika, 5(I), 53-62. https://doi.org//0.33084/jsm.v5il.945

9. Firdaus, M. D., Artanti, N., Hanafi, M., \& Rosmalena. (202I). Phytochemical constituents, and in vitro antidiabetic and antioxidant properties of various extracts of kenikir (cosmos caudatus) leaves. Pharmacognosy Journal, 13(4), 890-895. https://doi.org//0.5530/pj.2021.13.114

10. Januarti, I. B., Taufiq, H., \& Sulistyaningsih. (20I9). THE CORRELATION OF TOTAL FLAVONOID AND TOTAL PHENOLIC WITH ANTIOXIDANT ACTIVITY OF SINGLE BULB GARLIC (Allium sativum) FROM TAWANGMANGU AND MAGETAN. Jurnal Farmasi Sains Dan Komunitas, I6(2), 96-103.

II. Wahyuni, O. T., \& Hertiani, T. (20|6). DPPH RADICAL SCAVENGING ACTIVITY, TOTAL PHENOLICS AND FLAVONOIDS OF WATER SOLUBLE EXTRACTS DERIVED FROM LEAVES AND FRUIT OF Ficus carica L. AND Ficus parietalis BI. Traditional Medicine Journal, 2 I (2), 8692. https://doi.org//0.22146/tradmedj. 12822

12. Indarti, K., Apriani, E. F., Wibowo, A. E., \& Simanjuntak, P. (2019). Antioxidant Activity of Ethanolic Extract and Various Fractions from Green Tea (Camellia sinensis L.) Leaves. Pharmacognosy Journal, II(4), 77I-776. https://doi.org/10.5530/pj.2019.11.122

13. Jun, M., Fu, H., Hong, J., Wan, X., Yang, C., \& Ho, C. (2003). Comparison of Antioxidant Activities of Isoflavones from Kudzu Root (Pueraria labata Ohwi). J Food Sci Technol, 68(6). 